\title{
Subcutaneous dirofilariosis (Dirofilaria repens): an infection spreading throughout the old world
}

\author{
Claudio Genchi ${ }^{1 *}$ and Laura Kramer ${ }^{2}$ \\ From 15th American Heartworm Society Triennial Symposium \\ New Orleans, LA, USA. September 11-13, 2016
}

\begin{abstract}
Background: Two main Dirofilaria species infect dogs: D. immitis and D. repens. While D. immitis has a worldwide distribution, D. repens is currently found only in Europe, Asia, and Africa. Adult D. repens are located in subcutaneous tissues of natural hosts where they survive for long periods of time. First-stage larvae, microfilariae, circulate in the peripheral bloodstream, where they are taken up by the mosquito intermediate hosts. Infected mosquitoes then transmit infective third-stage (L3) larvae to new hosts through the blood meal. In dogs, most infections are asymptomatic, although cutaneous disorders such as pruritus, dermal swelling, subcutaneous nodules, and ocular conjunctivitis can be observed. Currently, two factors have increased the concerns about this parasitic infection 1) its spread throughout the European countries and to other continents and its prevalence in dog populations, where in some cases it has overcome D. immitis; and 2) its zoonotic potential, which is much greater than that of D. immitis.

Results: Different hypotheses can be put forward to explain these concerns. First, climate change has allowed more favorable conditions for survival of culicid vectors. Second, accidental hosts such as humans may have a less efficient immune reaction against a parasite that is located in subcutaneous tissues, and thus less exposed to the host's immune response than, for instance, D. immitis. Furthermore, the absence of clinical signs in the majority of canine infections and the difficulty in diagnosing the infection, due to the lack of serologic tests and thus the reliance on the identification of microfilariae and differentiation from D. immitis to confirm the presence of the parasite, favor the further spread of this species. Finally, among the macrocyclic lactones currently used to prevent heartworm infection, only moxidectin has been found to be fully effective against the infective larvae transmitted by mosquitoes and partially effective (efficacy 96\%) against adult D. repens in experimental studies.
\end{abstract}

Conclusions: Dirofilaria repens infection is much more difficult than D. immitis to diagnose and control in the reservoir population (microfilaremic dogs). In addition, lack of familiarity with $D$. repens infection could lead to lack of vigilance underestimation for this parasite. The number of human cases in Europe and Asia is currently a serious public health concern. Medical doctors and veterinarians must collaborate closely for better control and surveillance of $D$. repens infection.

Keywords: Dirofilaria repens, Subcutaneous dirofilariosis, Zoonosis

\footnotetext{
*Correspondence: claudio.genchi@unimi.it

'Dipartimento di Medicina Veterinaria, Università degli Studi di Milano, 20133

Milan, Italy

Full list of author information is available at the end of the article
} 


\section{Background}

Dirofilarial infections are vector-borne parasitic diseases mainly of dogs, cats, and wild carnivores caused by Dirofilaria (Noctiella) repens and D. immitis. D. repens is endemic in many countries of the Old World but has not yet been found in the Americas (reports from Brazil and Peru $[1,2]$ are doubtful and need confirmation), while $D$. immitis infections have a worldwide distribution [3]. The two parasites were confused for many years and it was assumed that $D$. immitis worms could be found both in the pulmonary artery and in subcutaneous tissues. In 1910, Bonvicini [4], an Italian scientist, while studying the effect of essential turpentine oil against what he supposed were heartworms, recovered some adult worms from subcutaneous tissues of a necropsied dog and sent them to Raillet and Henry in Lyon (France), who subsequently described and named the species D. repens [5]. Nonetheless, the first observation of $D$. repens was probably from a human being. In 1566, a Portuguese medical doctor, Amato Lusitano, reported in his Curationum Medicinalium Centuriae: "puella trima ... per oculi internam partem, quam angulum magnum appellamus, a jumbrici cuiusdamcaput appere coepis..." (in a three-year-old girl, suddenly it started to appear in the area we call big angle of the eye the tip of one worm which sometimes are sited in the eye making its opacity) [6].

D. repens has a long pre-patent period (170-238 days) [7], although in a recent experimental study the first microfilariae were found in the bloodstream on day 164 post infection [8]. Infective larvae migrate throughout the subcutaneous tissue and muscular connective fasciae, where they develop to the adult stage and reside permanently. Adult worms and microfilariae are longliving parasites in their natural hosts (about 4 years). The parasite, like other filarioids, harbors an endosymbiont bacterium (Wolbachia) that plays a significant role in desensitization of host innate immunity, assuring the worms' long-term survival [9]. Interestingly, no inflammatory reaction or connective tissue capsule surrounds the living parasite, which can be seen moving actively under the connective serous layers $[8,10]$. In most cases, including experimental infections, the infection goes unnoticed (no clinical signs) $[8,10]$. Occasionally, cutaneous disorders such as pruritus, dermal swelling, subcutaneous nodules containing the parasite, and ocular conjunctivitis can be observed [11]. Allergic reactions likely due to microfilaria sensitization and Wolbachiamediated inflammatory reactions in severe infections have been reported [12]. In these cases, circulating microfilariae often are absent.

\section{Canine infections}

Infected dogs are the main reservoir of $D$. repens infection as they frequently have microfilariae in the peripheral blood. Since the early 1900 s, canine $D$. repens infection has been reported as endemic in central and southern Italy and in other southern European countries, such as France, Greece, and the former Yugoslavia [13]. Several factors have contributed to the spread of canine $D$. repens infection. The introduction of the Pet Travel Scheme in 2000 allowed easier movement of companion animals throughout the European Union [14]. Rising temperatures have resulted in the spread throughout Europe of the Asian tiger mosquito (Aedes albopictus) and other competent vector species such as Ae. koreicus [15]. Currently new endemic areas have been identified and confirmed in Austria, Czech Republic, Germany, Hungary, Poland, Russia, Ukraine, Slovakia, Turkey, and the Balkan Peninsula (Albania, Bosnia, Bulgaria, Croatia, Greece, Macedonia, Romania, Serbia) [16-19]. It is noteworthy that in several eastern European countries $D$. repens prevalence is higher than $D$. immitis: for example, in Romania, where the heartworm prevalence ranges $02 \%$ to $2 \%$ and the $D$. repens prevalence range is from $7 \%$ to $20 \%$ [20-22].

\section{Human infections}

Humans can be accidental hosts for both $D$. immitis and D. repens. Comparing the data of zoonotic infections caused by $D$. immitis in the United States and Japan with that observed in Europe in recent years, however, the figures are surprisingly different. Approximately 110 human cases of $D$. immitis have been reported in the US in the last 50 years $[23,24]$ and 277 cases in the last 39 years in Japan [25], while in Europe about 25 cases have been reported in the last 37 years [26-28]. It is noteworthy that the prevalence of canine heartworm infection in endemic areas of the US, Japan, and Europe is essentially the same (12\% to $60 \%$ in dogs not given preventives). For D. repens, more than 3500 human cases were reported in Europe from 1977 to 2016 [13, 16, 29-32]. Furthermore, three cases have been described in the US in individuals who acquired the infection during travel to Italy, Greece, and Africa [33-35]. The question is why does $D$. repens have such a high zoonotic potential in comparison with $D$. immitis?

\section{Dirofilaria immitis vs Dirofilaria repens: Why such a difference in the prevalence of human infections?}

Currently, there is no evidence indicating the existence of a more virulent $D$. immitis strain in the Americas than in Europe, although recently genetic differences have been observed in worms from human ocular infections both in the Americas and Europe [36, 37], suggesting the existence of a closely related species of Dirofilaria [38]. Concerning D. repens, while a clear genetic difference has been found among $D$. repens-like worms from Asia (India and Thailand) and between the 
Asian and the European samples, the genetic variability within the European samples is rather low [39].

One hypothesis to justify such a difference in the zoonotic potential between the two species could be a consequence of an unidentified factor related to the vector. Both $D$. immitis and $D$. repens, however, are able to grow in the same mosquito species and at the same temperature and humidity under laboratory conditions. In addition, both species have the same developmental time from the microfilarial stage to the infective larva [7, 17]. Recently, D. repens larvae have been identified in Anopheles maculipennis and Aedes vexans from Slovakia and Austria $[40,41]$ and both $D$. immitis and D. repens in Culex pipiens from Germany and Italy [42, 43]. These mosquito species are well known as competent vectors for $D$. immitis [42]. Therefore, other factors must play a role in the difference in the risk of zoonotic infections between the two species.

In humans, once $D$. repens infective larvae are transmitted by an infected mosquito, in most cases the parasite is found in subcutaneous nodules or in the ocular conjunctiva, apparently near the points of infected mosquito bites [13], although some lung and tumor-like infections have been reported [44-46]. In most cases, the parasite is not able to develop to the sexually mature adult stage and infection is characterized by the presence of pre-adult worms, although at least four cases of microfilaremic zoonotic infections have been reported in Europe and Asia [16, 47]. We can hypothesize that it is much easier for a parasite located in subcutaneous tissues to escape the natural resistance (immune response) of unusual hosts, such as humans, than for D. immitis larvae that migrate within deep tissues where they could be killed by the immune system of the host [48].

Most canine D. repens infections are subclinical or the clinical signs are nonspecific, and most infections go undiagnosed. Furthermore, while several antigen test kits with high sensitivity and specificity are available for the serologic diagnosis of heartworm infection, no serologic test is available for $D$. repens. This also makes the diagnosis of occult infections, despite clinical suspicion, nearly impossible [49]. It is noteworthy that the lack of cross-reaction between $D$. repens and D. immitis [50] is due to the localization of the two parasites (subcutis and bloodstream, respectively) rather than to the specificity of the tests. The heat treatment of serum recently suggested to increase the test sensitivity [51] may increase the risk of cross-reactions between the two Dirofilaria species [52]. Examination of the blood for circulating microfilariae is strongly suggested for both Dirofilaria infections, but this is the only method of $D$. repens diagnosis. Many veterinarians, however, are not familiar with the Knott test, which allows for visualization and identification of microfilariae, particularly those in areas where the parasite has only been recently introduced.

\section{Prevention and adulticide treatment}

The efficacy of the macrocyclic lactones (ML) currently used to prevent $D$. immitis patent infections (ivermectin, milbemycin oxime, moxidectin, and selamectin) was assessed in several experimental laboratory studies and in field studies [3] and all were considered fully effective until the emergence of ML resistance in the United States [53]. No report of resistance has yet been published in Europe. Preventive efficacy against $D$. repens has been evaluated only for the oral ivermectin formulation at $6 \mu \mathrm{g} / \mathrm{kg}$ and $12 \mu \mathrm{g} / \mathrm{kg}$ [54] and both the injectable moxidectin formulation at $0.17 \mathrm{mg} / \mathrm{kg}$ and the topical moxidectin formulation at $2.5 \mathrm{mg} / \mathrm{kg}$ (in combination with imidacloprid) in experimental studies [10, 55]. Both moxidectin formulations showed full efficacy (100\%) while ivermectin showed an efficacy of $87 \%$ to 93\% [53]. Furthermore, most ML currently used to prevent dirofilarial infections are not fully efficacious against $D$. repens microfilariae; only moxidectin has been approved as a microfilaricidal agent and it must be administered in four monthly doses [56].

Against the adult stages of $D$. repens, the efficacy of melarsomine dihydrochloride currently used against $D$. immitis patent infections is doubtful. There is only one report of an effective treatment obtained with melarsomine plus doramectin in a dog naturally infected with $D$. repens [57], but the data was never confirmed and no efficacy was found in previous clinical studies (Genchi et al., 1996, unpublished). Recently, good adulticidal efficacy (96\%) was found in experimentally infected dogs treated monthly for 6 months with moxidectin $2.5 \mathrm{mg} / \mathrm{kg}$ body weight (plus imidacloprid $10 \mathrm{mg} / \mathrm{kg}$ body weight) [8].

There are several reasons that might explain the difference in efficacy between avermectins and milbemycins. Moxidectin is more lipophilic in nature than ivermectin and it is stored in the fat, which may act as a drug reservoir. Compared with ivermectin, moxidectin has a higher distribution volume and a longer half-life elimination. This may facilitate its distribution from the bloodstream to different tissues and longer residence time for the drug in the body $[58,59]$. Furthermore, the recommended dose rate of moxidectin against $D$. immitis infective larvae is $3 \mu \mathrm{g} / \mathrm{kg}$ vs $6 \mu \mathrm{g} / \mathrm{kg}$ of ivermectin [3]. Finally, $D$. repens larval stages and adult worms reside in the subcutaneous tissues, which are rich in fat and connective tissue.

Therefore, the higher lipophilic nature of moxidectin is probably the reason for the full efficacy observed in the studies. Furthermore, P-glycoprotein (P-gp) is a membrane protein belonging to the superfamily of the 
ATP-binding cassette $(\mathrm{ABC})$ transporters and exerts a potent action vs drug disposition. Moxidectin toxicity depends to a lesser extent on P-gp activity compared with ivermectin (moxidectin seems to be a weaker substrate inhibitor of P-gp than ivermectin [60]). This may explain the higher recommended dose rate of moxidectin vs ivermectin in dogs (eg, $2.5 \mathrm{mg} / \mathrm{kg}$ for moxidectin and $6 \mu \mathrm{g} / \mathrm{kg}$ for ivermectin), which therefore makes the spectrum of efficacy of this ML broader.

\section{Conclusions}

For all the reasons discussed in this article, $D$. repens infection is much more difficult than $D$. immitis to diagnose and control in the reservoir population (microfilaremic dogs). If the spread of $D$. repens continues, it is certainly possible that it could be introduced in the United States by translocation of infected dogs. In addition, while veterinarians and pet owners are aware of $D$. immitis infection [61], lack of familiarity with $D$. repens infection could lead to lack of vigilance underestimation for this parasite.

The number of human cases in Europe and Asia is currently a serious public health concern. On the other hand, we cannot exclude the possibility that the high zoonotic impact of $D$. repens is not merely a reflection of the more "visible" clinical signs in humans, eg, subcutaneous nodules and conjunctival and subconjunctival infections, which are easier to diagnose than $D$. immitis lung infections. Nonetheless, medical doctors and veterinarians must collaborate closely for better control and surveillance of $D$. repens infection. In the Ukraine, reporting cases of dirofilariosis has been mandatory since 1975, and the disease was included in the national surveillance system for notifiable diseases [31]. Guidelines for the control and treatment of $D$. repens infections can be found in the ESCCAP Guideline 5 [62].

\section{Abbreviations}

ESCCAP: European Scientific Counsel Companion Animal Parasites;

ML: Macrocyclic lactones

\section{Acknowledgements}

Not applicable.

\section{Funding}

The article's publication fee was funded by the American Heartworm Society.

\section{Availability of data and materials}

Not applicable.

\section{About this supplement \\ This article has been published as part of Parasites and Vectors Volume 10 Supplement 2, 2017: Proceedings of the 15th American Heartworm Society Triennial Symposium 2016. The full contents of the supplement are available online at https://parasitesandvectors.biomedcentral.com/articles/supplements/ volume-10-supplement-2.}

\section{Authors' contributions}

CG and LK have equally contributed to writing the article. Both authors have read and approved the final manuscript
Ethics approval and consent to participate

Not applicable.

\section{Consent for publication}

Not applicable.

\section{Competing interests}

The authors declare they have no competing interests.

\section{Publisher's Note}

Springer Nature remains neutral with regard to jurisdictional claims in published maps and institutional affiliations.

\section{Author details}

${ }^{1}$ Dipartimento di Medicina Veterinaria, Università degli Studi di Milano, 20133 Milan, Italy. ${ }^{2}$ Dipartimento di Scienze Medico Veterinarie, Università di Parma, Parma, Italy.

Published: 9 November 2017

\section{References}

1. Lent $\mathrm{H}$, de Frietas JFT. Dirofilariose sub-cutanea dos cães no Brasil. Mem Inst Osvaldo Cruz. 1937;32:443-8.

2. López J, Valente-Echeverrla F, Carrasco M, Mercado R, Abarca K Morphological and molecular identification of canine filariae in a semi-rural district of metropolitan region in Chile. Rev Chil Infectol 2012:29:284-289.

3. McCall JW, Genchi C, Kramer LH, Guerrero J, Venco L. Heartworm disease in animals and humans. Adv Parasitol. 2008; doi: 10.1016/S0065-308X(08)00204-2.

4. Bonvicini A. Di un caso di filariosi in un cane affetto da rogna demodettica. II Modeno Zoiatra, Parte Scientifica. 1910;42:55. [in Italian]

5. Raillet A, Henry A. Remarques sur sujet de deux notes de MM. Bouche et Bernard. Bull Soc Path Exot. 1911;4:485-8. [in French]

6. Lusitano A. Curationum Medicinalium Centuria Septima. Venetiis apud Vincentium Valgresium curatio 63, 1566, p 106 [in Latin].

7. Webber WAF, Hawking F. Experimental maintenance of Dirofilaria repens and D. immitis in dogs. Exp Parasitol. 1955;4:143-64.

8. Petry G, Genchi M, Schmidt H, Schaper R, Lawrenz B, Genchi C. Evaluation of the adulticidal efficacy of imidacloprid $10 \%$ /moxidectin $2.5 \%(\mathrm{~W} / \mathrm{v})$ spot-on (advocate, advantage multi) against Dirofilaria repens in experimentally infected dogs. Parasitol Res. 2015; doi: 10.1007/s00436-015-4519-7.

9. Genchi C, Kramer LH, Sassera D, Bandi C. Wolbachia and its implications for the immunopathology of filariosis. Endocr Metab Immune Disord Drug Targets. 2012;12:53-6.

10. Genchi M, Pengo G, Genchi C. Efficacy of moxidectin microsphere sustained release formulation for the prevention of subcutaneous filarial (Dirofilaria repens) infection in dogs. Vet Parasitol. 2010; doi:10.1016/j.vetpar.2010.01.034.

11. Albanese F, Abramo F, Braglia C, Caporali C, Venco L, Vercelli A, Ghibaudo G, Leone F, Carrani F, Giannelli A, Otranto D. Nodular lesions due to infestation by Dirofilaria repens in dogs from Italy. Vet Dermatol. 2013; doi: 10.1111/ vde.12009.

12. Rocconi F, Di Tommaso M, Traversa D, Palmieri C, Pampurini F, Boari A. Allergic dermatitis by Dirofilaria repens in a dog: clinical picture and treatment. Parasitol Res. 2012; doi: 10.1007/s00436-012-2833-x.

13. Pampiglione $\mathrm{S}$, Canestri-Trotti G, Rivasi F. Human dirofilariasis due to Dirofilaria (Nochtiella) repens: a review of world literature. Parassitologia. 1995;37:149-93.

14. Trotz-Williams LA, Trees AJ. Systematic review of the distribution of the major vector-borne parasitic infections in dogs and cats in Europe. Vet Rec. 2003:152:97-105.

15. Montarsi F, Ciocchetta S, Devine G, Ravagnan S, Mutinelli F, Frangipane di Regalbono A, Otranto D, Capelli G. Development of Dirofilaria immitis within the mosquito Aedes (Finlaya) koreicus, a new invasive species for Europe Parasit Vectors. 2015; doi: 10.1186/s13071-015-0800-y.

16. Genchi C, Kramer LH, Rivasi F. Dirofilarial infections in Europe. Vector Borne Zoon Dis. 2011; doi: 10.1089/vbz.2010.0247.

17. Genchi C, Mortarino M, Rinaldi L, Cringoli G, Traldi G, Genchi M. Changing climate and changing vector-borne disease distribution: the example of Dirofilaria in Europe. Vet Parasitol. 2011; doi: 10.1016/j.vetpar.2011.01.012.

18. Sassnau R, Daugschies A, Lendner M, Genchi C. Climate suitability for the transmission of Dirofilaria immitis and D. repens in Germany. Vet Parasitol. 2014; doi: 10.1016/j.vetpar.2014.06.034. 
19. Tasić-Otašević SA, Trenkić Božinović MS, Gabrielli SV, Genchi C. Canine and human Dirofilaria infections in the Balkan Peninsula. Vet Parasitol. 2015; doi: 10.1016/j.vetpar.2015.02.016.

20. Ilie MS, Imre K, Hotea I, Darabuş G. Survey of canine dirofilariosis from south-western Romania - preliminary results. In: Grandi G, Kramer L, Genchi C (Eds): 3rd European Dirofilaria Days. Parma, Italy, 2012, p 68, ISBN-13: 978-88903582-6-5.

21. Ciocan R, Mederle N, Jacsó O, Tánczos B, Fok É. Autochthonous cases of Dirofilaria in dogs from Timiş country (western part) Romania. Global J Med Res. 2013;13:29-34.

22. Ionică AM, Matei IA, Mircean V, Dumitrache MO, D'Amico G, Győrke A, Pantchev N, Annoscia G, Albrechtová K, Otranto D, Modrý D, Mihalca $A D$. Current surveys on the prevalence and distribution of Dirofilaria spp. and Acanthocheilonema reconditum infections in dogs in Romania. Parasitol Res. 2015;114:975-982. doi:10.1007/s00436-014-4263-4.

23. Theis $\mathrm{JH}$. Public health aspects of dirofilariasis in the United States. Vet Parasitol. 2005;133:157-80.

24. Lee AC, Montgomery SP, Theis JH, Blagburn BL, Eberhard ML. Public health issues concerning the widespread distribution of canine heartworm disease. Trends Parasitol. 2010;26:168-73.

25. Akao N. Human dirofilariasis in Japan. Trop Med Health. 2011; doi: 10.2149/ tmh.39-1-suppl_2-65.

26. Avellis FO, Kramer LH, Mora P, Bartolino A, Benedetti P, Rivasi F. A case of human conjunctival dirofilariosis by Dirofilaria immitis in Italy. Vector Borne Zoonotic Dis. 2011; doi: 10.1089/vbz.2010.0067.

27. Fossiac M, Million M, Mary C, Dales J-P, Souraud J-B, Piarroux, Parola P. Subcutaneous infection with Dirofilaria immitis nematode in human, France. Emerg Infect Dis. 2013; doi: 10.3201/eid1901.120281.

28. Falidas E, Gourgiotis S, Ivopoulou O, Koutsogiannis I, Oikonomou C, Vlachos K, Villias C. Human subcutaneous dirofilariasis caused by Dirofilaria immitis in a Greek adult. J Infect Public Health. 2016; doi: 10.1016/j.jiph.2015.06.005.

29. Pampiglione S, Rivasi F. Human dirofilariasis due to Dirofilaria (Nochtiella) repens: an update of world literature from 1995 to 2000. Parassitologia. 2000;42:231-54.

30. Simón F, Siles-Lucas M, Morchón R, González-Miguel J, Mellado I, Carretón E, Montoya-Alonso JA. Human and animal dirofilariasis: the emergence of a zoonotic mosaic. Clin Microbiol Rev. 2012; doi: 10.1128/CMR.00012-12.

31. Sałamatin RV, Pavlikovska TM, Sagach OS, Nikolayenko SM, Kornyushin W, Kharchenko VO, Masny A, Cielecka D, Konieczna-Sałamatin J, Conn DB, Golab E. Human dirofilariasis due to Dirofilaria repens in Ukraine, an emergent zoonosis: epidemiological report of 1465 cases. Acta Parasitol. 2013;58:592-8.

32. Fuehrer HP, Auer H, Leschnik M, Silbermayr K, Duscher G, Joachim A. Dirofilaria in humans, dogs, and vectors in Austria (1978-2014)-From imported pathogens to the endemicity of Dirofilaria repens. PLOS Negl Trop Dis. 2016; doi: 10.1371/journal.pntd.0004547.

33. Gardiner $\mathrm{CH}$, Oberdorfer CE, Reyes JE, Pinkus WH. Infection of man by Dirofilaria repens. Am J Trop Med Hyg. 1987;27:1279-81.

34. MacDougall LT, Magoon CC, Fritsche TR. Dirofilaria repens manifesting as a breast nodule. Diagnostic problems and epidemiologic considerations. Am J Clin Pathol. 1992;97:625-30.

35. Orihel TC, Helentjaris D, Alger J. Subcutaneous dirofilariosis: a simple inoculum, multiple worms. Am J Trop Med Hyg. 1997;56:452-5.

36. Otranto D, Diniz DG, Dantas-Torres F, Casiraghi M, de Almeida IN, de Almeida LN, dos Santos JN, Furtado AP, de Almeida Sobrinho EF, Bain O. Human intraocular filariasis caused by Dirofilaria sp. Nematode. Brazil. Emerg Infect Dis. 2011; doi: 10.3201/eid1705.100916.

37. Rossi A, Peix Á, Pavlikovskaya T, Sagach O, Nikolaenko S, Chizh N, Kartashev V, Simón F, Siles-Lucas M. Genetic diversity of Dirofilaria spp. isolated from subcutaneous and ocular lesions of human patients in Ukraine. Acta Trop. 2015;142:1-4.

38. Dantas-Torres F, Otranto D. Dirofilariosis in the Americas: a more virulent Dirofilaria immitis? Parasit Vectors. 2013; doi: 10.1186/1756-3305-6-288.

39. Yilmaz E, Fritzenwanker M, Pantchev N, Lendner M, Wongkamchai S, Otranto D, Kroidl I, Dennebaum M, Le TH, Anh Le T, Ramünke S, Schaper R, von Samson-Himmelstjerna G, Poppert S, Krücken J. The mitochondrial genomes of the zoonotic canine filarial parasites Dirofilaria (Nochtiella) repens and Candidatus Dirofilaria (Nochtiella) honkongensis provide evidence for presence of cryptic species. PLoS Negl Trop Dis. 2016; doi: 10.1371/journal.pntd.0005028.

40. Bocková E, Iglódyová A, Kočišová A. Potential mosquito (Diptera: Culicidae) vector of Dirofilaria repens and Dirofilaria immitis in urban areas of Eastern Slovakia. Parasitol Res. 2014; doi: 10.1007/s00436-014-4191-3.
41. Silbermayr K, Eigner B, Joachim A, Duscher GG, Seidel B, Allerberger F, Indra A, Hufnagl P, Fuehrer HP. Autochthonous Dirofilaria repens in Austria. Parasit Vectors. 2014; doi: 10.1186/1756-3305-7-226.

42. Cancrini G, Magi M, Gabrielli S, Arispici M, Tolari F, Dell'Omodarme M, Prati MC. Natural vectors of dirofilariasis in rural and urban areas of the Tuscan region, central Italy. J Med Entomol. 2006:43:574-9.

43. Kronefeld M, Kampen H, Sassnau R, Werner D. Molecular detection of Dirofilaria immitis, Dirofilaria repens and Setaria tundra in mosquitoes from Germany. Parasit Vectors. 2014; doi: 10.1186/1756-3305-7-30.

44. Rivasi F, Boldorini R, Criante P, Leutner M, Pampiglione S. Detection of Dirofilaria (Nochtiella) repens DNA by polymerase chain reaction in embedded paraffin tissues from two human pulmonary locations. APMIS. 2006;114:567-74.

45. Perret-Court A, Coulibaly B, Ranque S, Bouvier C, Lena G, Coze C, Verschuur A. Intradural dirofilariasis mimicking a Langerhans cell histiocytosis tumor. Pediatr Blood Cancer. 2009; doi: 10.1002/pbc.22114.

46. Leccia N, Patouraux S, Carpentier X, Boissy C, Del Giudice P, Parks S, Michiels JF, Ambrosetti D. Pseudo-tumor of the scrotum, a rare clinical presentation of dirofilariasis: a report of two autochthonous cases due to Dirofilaria repens. Pathol Glob Health. 2012; doi: 10.1179/2047773212Y. 0000000029.

47. Damle AS, Iravane Bajaj JA, Khaparkhuntikar MN, Maher GT, Patil RV. Microfilaria in human subcutaneous dirofilariasis: a case report. J Clin Diagn Res. 2014; doi: 10.7860/JCDR/2013/6886.

48. Brattig NW, Bazzocchi C, Kirschning CJ, Reiling N, Büttner DW, Ceciliani F, Geisinger F, Hochrein H, Ernst M, Wagner $H$, Bandi C, Hoerauf $A$. The major surface protein of Wolbachia endosymbionts in filarial nematodes elicits immune responses through TLR2 and TLR4. J Immunol. 2004;173:437-45.

49. Giori L, Garbagnoli V, Venco L, Genchi M, Bazzocchi C, Bertazzolo W. What is your diagnosis? Fine-needle aspirate from a subcutaneous mass in a dog. Mixed neutrophilic-eosinophilic inflammation with Dirofilaria fragments Vet Clin Pathol. 2010; doi: 10.1111/j.1939-165X.2009.00212.x.

50. Genchi C, Solari Basani F, Bandi C, Di Sacco B, Venco L, Vezzoni A, Cancrini G. Factors influencing the spread of heartworms in Italy. In: Soll MD, Knight $\mathrm{DH}$, editors. Proceedings of the heartworm symposium '95. Batavia, IL: American Heartworm Society; 1995. p. 65-71.

51. Little SE, Beall MJ, Bowman DD, Chandrashekar R, Stamaris J. Canine infection with Dirofilaria immitis, Borrelia burgdorferi, Anaplasma spp., and Ehrlichia spp. in the United States, 2010-2012 Parasit Vectors. 2014; doi: 10.1186/1756-3305-7-257.

52. Ciucă L, Genchi M, Kramer L, Mangia C, Miron LD, Prete LD, Maurelli MP Cringoli G, Rinaldi L. Heat treatment of serum samples from stray dogs naturally exposed to Dirofilaria immitis and Dirofilaria repens in Romania Vet Parasitol. 2016; doi: 10.1016/j.vetpar.2016.05.032.

53. Bowman DD. Heartworms, macrocyclic lactones, and the specter of resistance to prevention in the United States Parasit Vectors. 2012; doi: https://doi.org/10.1186/1756-3305-5-138.

54. Cancrini G, Tassi P, Coluzzi M. Ivermectin against larval stages of Dirofilaria repens in dogs. Parassitologia. 1989;31:177-82. [in Italian]

55. Genchi C, Genchi M, Petry G, Kruedewagen EM, Schaper R. Evaluation of the efficacy of imidacloprid 10\% / moxidectin 2.5\% (Advocate ${ }^{\circledast}$, Advantage ${ }^{\circledast}$ Multi, Bayer) for the prevention of Dirofilaria repens infection in dogs Parasitol Res. 2013; doi: 10.1007/s00436-013-3283-9.

56. European Medicines Agency (EMA). CVMP assessment report for type II variation for Advocate (EMEAN/C/000076/II/0022); 18 July 2013 EMA/ 506044/2013 Veterinary Medicines Division, 2013.

57. Baneth G, Volansky Z, Anug Y, Favia G, Bain O, Goldstein RE, Harrus S. Dirofilaria repens infection in a dog: diagnosis and treatment with melarsomine and doramectin. Vet Parasitol. 2002;105:173-8.

58. Alvinerie M, Sutra JF, Badri M, Galtier P. Determination of moxidectin in plasma by high-performance liquid chromatography with automated solidphase extraction and fluorescence detection. J Chromatogr B Biomed Appl. 1995;674:119-24.

59. Vanapalli SR, Hung YP, Fleckenstein L, Dzimianski MT, McCall JW. Pharmacokinetics and dose proportional- ity of oral moxidectin in beagle dogs. Biopharm Drug Dispos. 2002;23:263-72.

60. Lespine A, Martin S, Dupuy J, Roulet A, Pineau T, Orlowski S, Alvinerie M. Interaction of macrocyclic lactones with P-glycoprotein: structure-affinity relationship. Eur J Pharm Sci. 2007;30:84-94. 
61. Genchi C, Bowman D, Drake J. Canine heartworm disease (Dirofilaria immitis) in Western Europe: survey of veterinary awareness and perceptions. Parasit Vectors. 2014; doi: 10.1186/1756-3305-7-206..

62. European Scientific Counsel Companion Animal Parasites (ESCCAP).

Guideline 5: Control of Vector-Borne Diseases in Dogs and Cats, ed 2. 2012.

http://www.esccap.org/uploads/file/ESCCAP\%20-

Guidelines\%20GL5\%2001Oct2012.pdf.

Submit your next manuscript to BioMed Central and we will help you at every step:

- We accept pre-submission inquiries

- Our selector tool helps you to find the most relevant journal

- We provide round the clock customer support

- Convenient online submission

- Thorough peer review

- Inclusion in PubMed and all major indexing services

- Maximum visibility for your research

Submit your manuscript at www.biomedcentral.com/submit
Biomed Central 